\title{
Leaf area, spray volumes and applicable quantities of fungicide during the protection period for control of Asian soybean rust
}

\author{
Amanda Chechi ${ }^{1}$, Walter Boller ${ }^{2}$, Carlos Alberto Forcelini ${ }^{3}$, Rafael Roehrig $^{4}$, Elias Zuchelli ${ }^{5}$
}

\begin{abstract}
${ }^{1}$ Agronomy Doctoral Student at PPGAgro/UPF. E-mail: amandachechi@hotmail.com. University of Passo Fundo, BR 285, São José, Zip Code 99052-900, Passo Fundo/RS, Brasil. ${ }^{2}$ Professor of FAMV/UPF. University of Passo Fundo, BR 285, São José, Zip Code 99052-900, Passo Fundo/ RS, Brasil. ${ }^{3}$ Professor of FAMV/UPF. E-mail: forcelini@upf.br. University of Passo Fundo, BR 285, São José, Zip Code 99052-900, Passo Fundo/ RS, Brasil. ${ }^{4}$ Agronomy Doctoral Student at PPGAgro/UPF. E-mail: rafael.roehrig@yahoo.com.br. University of Passo Fundo, BR 285, São José, Zip Code 99052-900, Passo Fundo/RS, Brasil. 5. gronomist undergraduated by FAMV-UPF. E-mail: elias-zuchelli@hotmail.com. University of Passo Fundo, BR 285, São José, Zip Code 99052-900, Passo Fundo/RS, Brasil.
\end{abstract}

Autor para correspondência: Walter Boller (boller@upf.br)

Data de chegada: 16/01/2017. Aceito para publicação em: 15/09/2017.

$10.1590 / 0100-5405 / 174517$

\begin{abstract}
Chechi, A.; Boller, W.; Forcelini, C.A.; Roehrig, R.; Zuchelli, E. Leaf area, spray volumes and applicable quantities of fungicide during the protection period for control of Asian soybean rust. Summa Phytopathologica, v.44, n.4, p.326-331, 2018.

The purpose of this study was to check the influence of leaf area index, spray volumes and applicable quantities of fungicide during the protection period, and for control of Asian soybean rust. All tests were conducted in the field and in the laboratory between 2014 and 2016. The quantity of fungicide and the spray volume were varied in the application of fungicides on soybean plants with different leaf area index. Rainfall simulation tests were also carried out at

different times after application of fungicide. The spray volume and application rate of fungicide should be adequately proportioned according to the leaf area index of the soybean cultivar. The closer to the time of application that the rain occurs, the lower the control obtained by applying the fungicide. The leaf area index, the fungicide application rates, and the spray volumes influenced the protection period of fungicides and the control of Asian soybean rust.
\end{abstract}

Keywords: application technology, Phakopsora pachyrhizi, rainfall simulation

\section{RESUMO}

Chechi, A.; Boller, W.; Forcelini, C.A.; Roehrig, R.; Zuchelli, E. Área foliar, volumes de calda e doses de fungicida no período de proteção e no controle da Ferrugem-asiática-da-soja. Summa Phytopathologica, v.44, n.4, p.326-331, 2018.

O objetivo deste trabalho foi verificar a influência do índice de área foliar, volumes de calda e de doses de fungicidas no período de proteção e no controle da ferrugem-asiática-da-soja. Os ensaios foram conduzidos a campo e em laboratório, entre 2014 e 2016. Variou-se a dose e o volume de calda na aplicação de fungicidas sobre plantas de soja com diferentes índices de área foliar. Também foi realizado um ensaio com simulação de chuva em diferentes momentos após a aplicação de fungicidas. O volume de calda e a dose do fungicida devem ser adequados de acordo com o índice de área foliar da cultivar. Quanto mais próximo do momento da aplicação a chuva ocorrer, menor o controle obtido pela aplicação do fungicida. O índice de área foliar, as doses e os volumes de calda influenciam o período de proteção de fungicidas e no controle da ferrugem-asiática-da-soja.

Palavras-chave: Phakopsora pachyrhizi, simulação de chuva, tecnologia de aplicação

Asian soybean rust (ASR) caused by the fungus Phakopsora pachyrhizi Sydow \& Sydow is one of the most severe diseases affecting soybean, with damage varying from 10 to $90 \%$ in the different places from where it was reported (20,22). Santos et al. (19), stated that the control of the disease is mainly based on fungicide applications. The effectiveness of the chemical control of the disease depends on several factors among which are: the choice of effective fungicides; time of application; interval time between applications; spray volume; and the adequacy of the application technology to the target and to the culture (4).

According to Debortoli et al. (8), soybean cultivars with greater branching capacity and leaf quantity need a greater droplet coverage. Soybean cultivars vary in leaf area index, from 3.5 to more than 8.0. It is reasonable to assume that the same spray volume used in spraying does not distribute a uniform quantity of fungicide in plants of different size and leaf area. The same can be inferred from the fungicide rates used in the soybean crop. In this sense, the spray volume and the quantity of chemicals used should be adjusted in proportion to the leaf area of the plant to be protected. Otherwise, there may be excess coverage in plants of smaller size, and insufficient protection in plants with larger leaf area, which will affect the efficacy of disease control.

The protection period of the fungicides applied on the leaves can be affected by plant characteristics and also by environmental factors. Among the environmental factors, rainfall occurrence may interfere in pesticide performance (18). According to Oliveira (17), rain is one of the main causes of loss, and it is responsible for washing away the fungicide deposits on the plants, thus diluting, redistributing and completely removing the fungicide.

The purpose of this work was to check the influence of leaf area index, spray volumes and applicable quantities of fungicide during the protection period, and for control of ASR. 


\section{MATERIAL AND METHODS}

The experiments were conducted in the experimental field, greenhouse and growth chamber in the University of Passo Fundo, located in the city of Passo Fundo - RS at an altitude of $687 \mathrm{~m}$. The place is located in the latitude of $28^{\circ} 15^{\prime} \mathrm{S}$ and longitude of $52^{\circ} 24^{\prime} \mathrm{W}$.

The field trial was carried out during the 2014/15 season, with three soybean cultivars of indeterminated habit, with IPRO technology (Intacta RR2 PRO), and with different leaf area index (LAI): NS 5445 $(\mathrm{LAI}<6)$, BMX Vanguarda (LAI $=6$ to 7 ), BMX Ponta (LAI $>7$ ). The experimental design was in randomized blocks, with five replications. Each plot measured $2.25 \mathrm{~m} \times 5.0 \mathrm{~m}$ with five rows. The distance between blocks was $0.9 \mathrm{~m}$, and was $1.2 \mathrm{~m}$ between plots.

The soil is classified as Dystrophic Dark Red Latosol. The accumulated rainfall in the months of December 2014 and January, February and March of 2015 was recorded as $696.8 \mathrm{~mm}, 73.2 \mathrm{~mm}$ above the historical normal for the period in the area. However, almost half of the precipitation occurred in the month of January (333.5 mm). The average temperatures recorded during the period were similar to the historical normal $\left(21^{\circ} \mathrm{C}\right)$, being slightly above it in the minimum $\left(17^{\circ} \mathrm{C}\right)$, and below the maximum temperatures $\left(28^{\circ} \mathrm{C}\right)(10,11)$.

The sowing was at the end of November, on wheat cultural remains, with spacing of $0.45 \mathrm{~m}$ between rows. The sowing density of NS 5445, BMX Vanguarda, and BMX Ponta were 14, 12 and 10.5 seeds per meter, totaling 345,680, 296,296 and 259,260 established plants per hectare. The management of weeds, pests and insects was carried out according to the official technical methods for the crop (16).

Three fungicide applications were administered. In the first application, it was trifloxystrobin + prothioconazole (commercial rate: $60+70 \mathrm{~g}_{\text {a.i. }} \mathrm{ha}^{-1}$ ) plus vegetable oil composed of methyl ester of soybean oil ( $360 \mathrm{~g}$ a.i. ha $\left.{ }^{-1}\right)$ at 48 days after sowing (DAS). In the second and third applications, we used azoxystrobin + benzovindiflupyr

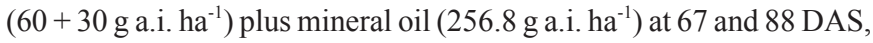
respectively. The fungicides were applied in three spray volumes (100, 150 and $\left.200 \mathrm{~L} \mathrm{ha}^{-1}\right)$ and at three rates $(75,100$ and $125 \%$ of the rate recommended by the manufacturer), characterizing a $3 \times 3$ factorial scheme.

$\mathrm{ACO}_{2}$ pressurized sprayer equipped with a four-nozzle bar (spaced $0.5 \mathrm{~m}$ apart) with flat spray tips of Teejet ${ }^{\mathbb{R}} \mathrm{XR} 110015$ series at a pressure of $2.0 \mathrm{bar}(200 \mathrm{kPa})$ was used for the application of the spray volumes of 100 and $150 \mathrm{~L} \mathrm{ha}^{-1}$. The Teejet ${ }^{\circledR}$ XR 11002 tips at pressure of 3 bar
$(300 \mathrm{kPa})$ were used for the volume of $200 \mathrm{~L} \mathrm{ha}^{-1}$. Both tips generated fine-grade drops.

Disease severity assessments were performed biweekly from the date of the first application of fungicide. Three plants were collected per plot, and the severity was evaluated according to the diagrammatic scale proposed by Godoy et al. (12). Among the 55 and 100 DAS, three plants per plot of each soybean cultivar were collected to measure the leaf area index using a LI-3100 $\mathrm{C}^{\circledR}$ area meter. The leaf area of the plants was multiplied by their populations to estimate the LAI.

The harvest was carried out in $6.75 \mathrm{~m}^{2}$ of each plot (three central rows). The humidity of the grains (\%), yield $\left(\mathrm{kg} \mathrm{ha}^{-1}\right)$, and mass of one thousand seeds $(\mathrm{g})$, with humidity adjustment to $13 \%$ were determined.

For the laboratory test $(2015 / 2016)$, a completely randomized experimental design was used, employing four replications. Three ND 5445 soybean seeds were sown in pots of $2000 \mathrm{~mL}$ in a greenhouse. After germination, only one soybean plant per pot was maintained.

When the plants completed 40 DAS, they were subjected to the same treatments as in the field experiment, using the fungicide azoxystrobin + benzovindiflupyr $\left(60+30 \mathrm{~g}\right.$ a.i. ha $\left.^{-1}\right)$ plus mineral oil $\left(256.8 \mathrm{~g}\right.$ a.i. $\left.\mathrm{ha}^{-1}\right)$. After the spraying which was carried out in the same manner as in the field experiment, the plants were exposed to an artificial rainfall of $20 \mathrm{~mm}$ at different times: $0.5 ; 1.0 ; 1.5 ; 2.0 ; 2.5$ and 3.0 hours after application of the fungicide. The plants remained for 14.5 minutes exposed to rain simulation for the formation of that water slide. The control treatment was kept (one with and the other without fungicide application), both without wetting. Then, the central leaflets of the seventh leaf of each soybean plant were removed. The methodology of detached leaf test used was adapted from Mehl \& Scherb (14).

At the laboratory, gerbox boxes were used, in which humidity chambers were created with a unit of polyethylene foam of the size of the gerbox $\left(121 \mathrm{~cm}^{2}\right)$ and two sheets, of the same size, of filter paper. The chambers were moistened with distilled water. Then, the leaflets were placed in the gerbox boxes with the adaxial side facing up, and left in the shade to dry at room temperature. Twenty-four hours after fungicide application, the leaflets were inoculated with a suspension of $P$. pachyrhizi spores $\left(5 \times 10^{4}\right.$ spores $\left.\mathrm{mL}^{-1}\right)$. The inoculum, obtained from soybean leaflets collected in the field, was taken to the laboratory for the preparation of the spore suspension. To a quantity of $500 \mathrm{~mL}$ Erlenmeyer, $200 \mathrm{~mL}$ of distilled water was added, one drop of Tween ${ }^{\circledR}$ spreader and soybean leaflets with rust. After shaking, the leaves were separated from the spore suspension. With a micropipette, $10 \mu \mathrm{L}$ aliquot

Table 1 - Spray volumes and fungicide rates used in the applications. Passo Fundo/RS, 2015

\begin{tabular}{ccccc}
\hline Treatment & Spray volume $\left(\mathrm{L} \mathrm{ha}^{-1}\right)$ & $\begin{array}{c}\text { Fungicide commercial } \\
\text { rate }(\%)\end{array}$ & $\begin{array}{c}\text { Trifloxystrobin }+ \text { prothioconazole } \\
\left.(\mathrm{g} \mathrm{a.i.} \mathrm{ha})^{-1}\right)\end{array}$ & $\begin{array}{c}\text { Azoxystrobin }+ \\
\text { benzovindiflupyr } \\
\left.(\mathrm{g} \mathrm{a.i.} \mathrm{ha})^{-1}\right)\end{array}$ \\
\hline 1 & - & - & - & - \\
2 & 100 & 100 & $60+70$ & $70+30$ \\
3 & 100 & 125 & $75+87.5$ & $75+37.5$ \\
4 & 100 & 75 & $45+52.5$ & $45+22.5$ \\
5 & 150 & 100 & $60+70$ & $60+30$ \\
6 & 150 & 125 & $75+87.5$ & $75+37.5$ \\
7 & 150 & 75 & $45+52.5$ & $45+22.5$ \\
9 & 200 & 100 & $60+70$ & $60+30$ \\
10 & 200 & 125 & $75+87.5$ & $75+37.5$ \\
4
\end{tabular}


of the suspension was taken and placed on a slide, covered by a cover slip and visualized under an optical microscope for spore counting. This procedure was repeated three times and the mean of the counts was calculated. The suspension was placed in a $500 \mathrm{~mL}$ spray bottle and applied to the leaflets.

For germination of the spores, the gerbox boxes were left in the dark for $24 \mathrm{~h}$, with a temperature of $23^{\circ} \mathrm{C}$. After this period, they were arranged in benches in a growth chamber, with a photoperiod of $12 \mathrm{~h}$, at the same temperature. Every 2 days, water was added to the gerbox boxes with a pissette, for moisture maintenance. After 20 days of incubation, pustules were counted per $\mathrm{cm}^{2}$ of each leaflet. For this, an area of $2.0 \mathrm{~cm}^{2}$, being $1.0 \mathrm{~cm}^{2}$ on each abaxial half of the leaflets, was evaluated under a stereoscopic microscope.

The disease severity data from the field experiment were submitted to $\log$ transformation $(\log \mathrm{x})$. For the disease control percentage calculation, the Abbott (1) formula was used. We used the F test for variance analysis, the Skott-Knott test for means classification and polynomial regression.

\section{RESULTS AND DISCUSSION}

The fungicide rate and the spray volume influenced the ASR severity, the green leaf area index, and the soybean grain yield in the field experiment, but there were no significant interactions between the factors. The ASR severity in the control reached 52\% (cv. NS 5445), 65\% (BMX Vanguarda) and 78.5\% (BMX Ponta) (Figure 1). These differences on final severity occurred mainly due to differences between cultivars. One of the factors that generated this difference in disease severity was the plant's leaf area.

The most effective treatments in reducing the severity of ASR for cv. NS 5445 were both with 100 and $125 \%$ of the commercial rate of the fungicide with the use of the spray volume of $200 \mathrm{~L} \mathrm{ha}^{-1}$. For cv. BMX Vanguarda, the best treatments were with the addition of $25 \%$ in the commercial rate using the spray volume of the $150 \mathrm{~L} \mathrm{ha}^{-1}$ and the rates of 100 and $125 \%$ for the spray volume of $200 \mathrm{~L} \mathrm{ha}^{-1}$. In cv. BMX Ponta, the treatment with the lowest disease severity was composed of the spray volume of $200 \mathrm{~L} \mathrm{ha}^{-1}$ and a $25 \%$ increase in the commercial rate of the fungicide, evidencing that the larger the leaf area, the lower the coverage. These data showed the need to increase the spray volume and, in some cases, the quantity of fungicide.

The highest values of leaf area index were 5.9 (cv. NS 5445) 7.2 (BMX Vanguarda) and 8.2 (BMX Ponta) in the best treatments, among stages R1 and R3. For cv. NS 5445, the leaf area index at the end of the grain filling was higher than in the other cultivars, being 2.9 (NS 5445), 2.2 (BMX Vanguarda) and 2.0 (BMX Ponta) (15, 18 and 25\% of severity, respectively) confirming the hypothesis that different spray volumes and fungicide rates are required to control the disease in soybean cultivars with a different leaf area index. At the end of the seed filling, the leaf area index showed its lowest value for the control in all experiments. According to Butzen et al. (2) in cultivars with higher quantity of leaves, the increase in the spray volume may provide sufficient coverage and penetration to protect soybean leaves. In a study by Navarini et al. (15), in which different rates of fungicides were evaluated, it was observed that the rate increase was efficient for some fungicides of the triazoles group in the control of soybean rust, which reflected higher grain yield.

The leaf area index and seed yield correlated positively for all cultivars, showing that the higher the leaf area index in R6 stage, the higher the yield. These results were obtained by the fungicide treatment, which better controlled the disease and kept the leaf area healthier.

Plant architecture, which is represented by their stature, number of branches and leaf area, have a significant effect on the coverage and penetration of drops in soybean cultivars. There are lower penetration of canopy drops in those plants with greater branching capacity and greater leaf area (7). The results obtained by Tormen et al. (21) showed that fungicide coverage of leaves of the lower third of the canopy of the soybean plant is dependent on the architectural characteristics of the cultivar at the time of application. Soybean cultivars with upright habit, which do not close completely between rows throughout the soybean cycle are available in the market. In this way, their use could contribute to improving the deposition of the fungicide in the lower parts of the canopy.

The lowest values of seed yield were observed in the control. All other treatments resulted in higher seed yield. Values ranged from 55 to $95 \%$ for cv. NS 5445 . For cv. BMX Vanguarda, the seed yield was 10 to $66 \%$ higher than the control. Already, for the cv. BMX Ponta, the

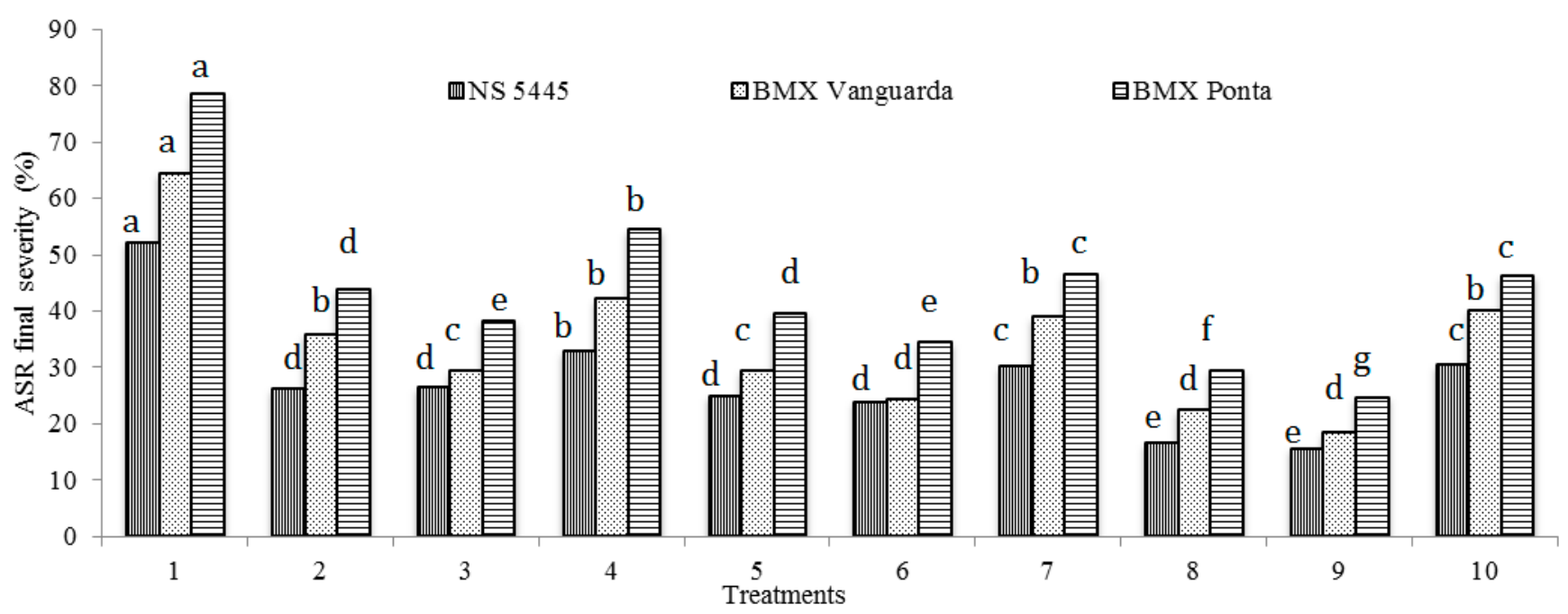

Figure 1 - Final severity of the Asian soybean rust according to each cultivar and treatment. 

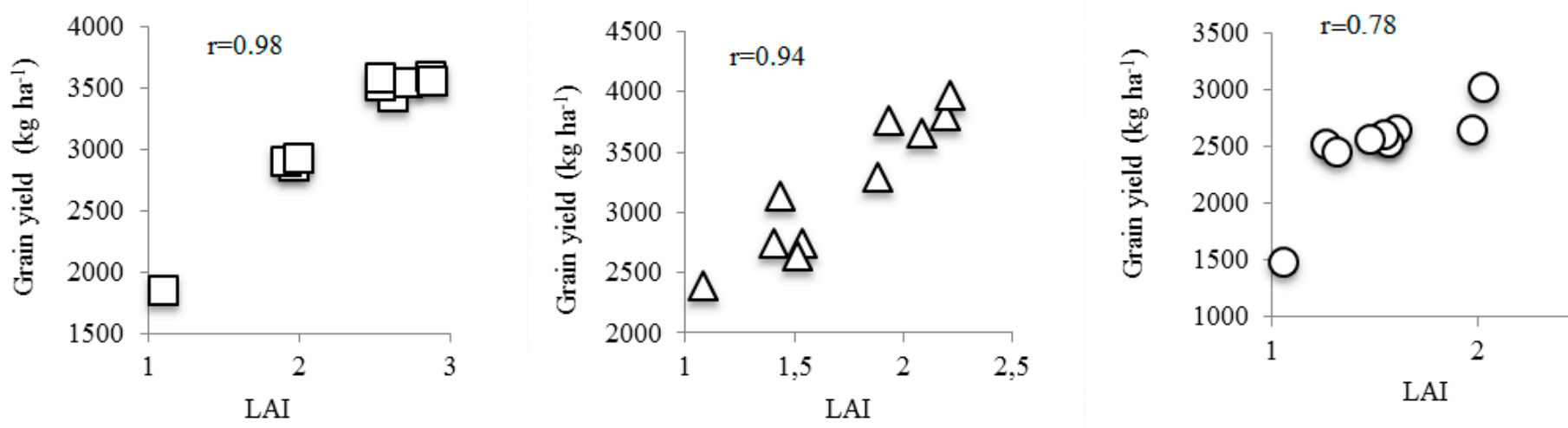

Figure 2 - Correlation between the leaf area index at the grain final filling (R6 stage) with the grain yield of each soybean cultivar $($ square $=$ NS 5445; triangle $=$ BMX Vanguarda; circle $=$ BMX Ponta)

yield ranged between 65 and $103 \%$ when compared to the control treatment. Regarding yield, for cv. NS 5445, the treatment with the $100 \mathrm{~L} \mathrm{ha}^{-1}$ spray volume and the commercial rate of the fungicide proved to be the most appropriate since there was no difference between the spray volumes nor between the commercial rate and the one $25 \%$ higher. For cv. BMX Vanguarda, a spray volume of at least $150 \mathrm{~L} \mathrm{ha}^{-1}$ was required along with the commercial rate of the fungicide for a satisfactory control of the disease. The volume of 200 $\mathrm{L} \mathrm{ha}^{-1}$ and the rate $25 \%$ higher were statistically similar to them. In this case, the spray volume of $100 \mathrm{~L} \mathrm{ha}^{-1}$ was shown to be lower in the ASR control. Already, for cv. BMX Ponta, the best control was obtained with $200 \mathrm{~L} \mathrm{ha}^{-1}$ and a $25 \%$ increase in the commercial rate. The rates of $75 \%$ of the chemical did not present efficient control for the disease, regardless of the spray volume applied, with damages of more than $500 \mathrm{~kg} \mathrm{ha}^{-1}$ when compared to the most effective treatments.

For the laboratory experiment, a cause and effect relationship was found, showing that the sooner rainfall occurs after an application, the lower the disease control, in this case, represented by the increase in the number of pustules per $\mathrm{cm}^{2}$ (Figure 3 ). The influence of rain during the plant protection period is highly dependent on the time interval between the application of the products and its occurrence, besides the product being applied (13).

The control, without application of fungicide, presented an average of 97 pustules per $\mathrm{cm}^{2}$. For the spray volume of $100 \mathrm{~L} \mathrm{ha}^{-1}$, the number of pustules per $\mathrm{cm}^{2}$ was lower for treatment with $125 \%$ of the commercial rate, as compared to the $100 \%$ rate of treatment. With the use of $150 \mathrm{~L} \mathrm{ha}^{-1}$, the $25 \%$ higher fungicide rate presented a lower number of pustules per $\mathrm{cm}^{2}$ when rainfall occurred in the first few hours after application. When the rain occurred 2 hours after spraying, the treatment with $100 \%$ of the rate presented the lowest number of pustules per $\mathrm{cm}^{2}$. For the volume of the $200 \mathrm{~L} \mathrm{ha}^{-1}$, in the first few hours of rainfall after application, the $25 \%$ increase in commercial rate showed the lowest number of pustules per $\mathrm{cm}^{2}$. However, 2 hours after spraying, the pustules values per $\mathrm{cm}^{2}$ were similar for 100 and $125 \%$ of the fungicide rate.

The treatment with $75 \%$ of the commercial rate, regardless of the volume applied, generated the highest values of pustules per $\mathrm{cm}^{2}$, being the treatments less effective in the control of soybean rust, well agreeing with the experiment in the field. These results reinforce the use of adequate rates and spray volumes to the conditions, both environmental and the characteristics of the cultivar to be used.
The Asian rust control ranged from 90.7 to $97.4 \%$ for treatments that were not submitted to artificial rainfall. As for the treatments that were submitted to the rainfall simulator, the percentage of control varied between 24.7 and $55.7 \%$ ( $0.5 \mathrm{~h}$ after application); 41.8 and $61.9 \%(1.0 \mathrm{~h}) ; 44.8$ and $71.1 \%(1.5 \mathrm{~h}) ; 67.0$ and $78.4 \%$ $(2.0 \mathrm{~h}) ; 74.2$ and $84.5 \%$ (2.5 h); 80.7 and $94.6 \%$ (3.0 h). Debortoli (6) found that the occurrence of rain had a negative effect on the control of Asian rust, and it is directly related to the interval between the application and the occurrence of rainfall. The author observed that the simulation of rain at 0 and 30 minutes after the application of fungicide showed the greatest influence on the efficacy of the disease control.

When estimating the percentage of reduction in the effectiveness of the fungicide caused by rainfall, losses were observed between 45.1 and $66 \%$ ( $0.5 \mathrm{~h}$ after application of the fungicide); 35.6 and $50.0 \%$ (1.0 h); 26.3 and $45.9 \%$ (1.5 h); 18.3 and 26.8\% (2.0 h); 12.6 and $18.6 \%(2.5 \mathrm{~h}) ; 2.8$ and $10.1 \%(3.0 \mathrm{~h})$. With the occurrence of rainfall only 1 hour after application, the majority of the treatments presented about $50 \%$ reduction in the control effectiveness of Asian rust, while the treatments composed of spray volume of $200 \mathrm{~L} \mathrm{ha}^{-1}$ and 100 and $125 \%$ of the fungicide rate showed losses around $35 \%$. An explanation for such situations is that the use of a larger volume of spray provides a greater coverage and penetration of the active ingredient in the leaflet, resulting in a greater percentage of disease control. In works carried out by Cunha et al. $(3,5)$, it has been observed that there is a tendency towards increase in the deposition of the product with the increase of the spray volume. Derksen \& Sanderson (9) reported higher coverage and lower fungicide deposition variations throughout the canopy of soybean plants, with increasing volume of application.

Even 3 hours after application of the fungicide, there was still a reduction in the amount of active ingredient in the leaflets. In an experiment conducted by Oliveira (17), the values observed 1, 2 and 48 hours after application did not reflect the common sense of the fungicide market, which recommends a minimum interval of 2 hours between application and rainfall.

Rational use of fungicides requires adjusting the fungicide rate and the spray volume to the leaf area index of the soybean cultivar for a better and more efficient control of Asian rust. The occurrence of rain until 3 hours after the application of fungicide reduced the effectiveness of disease control. 

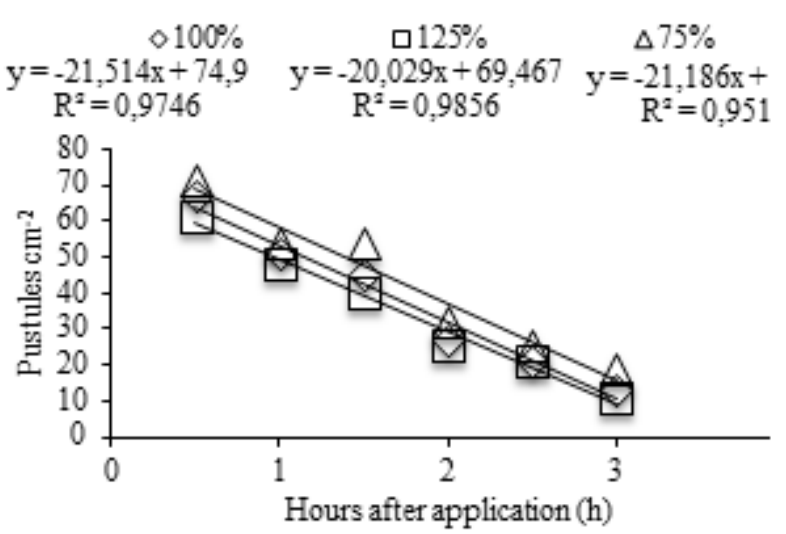

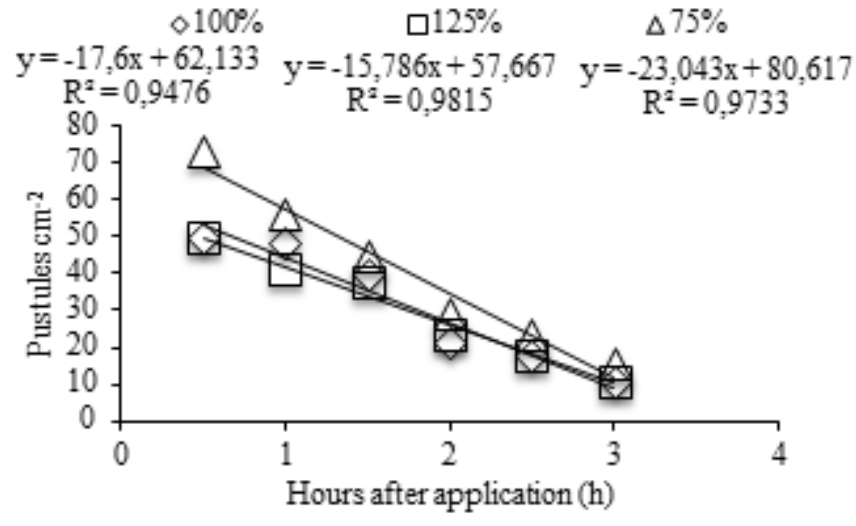

A

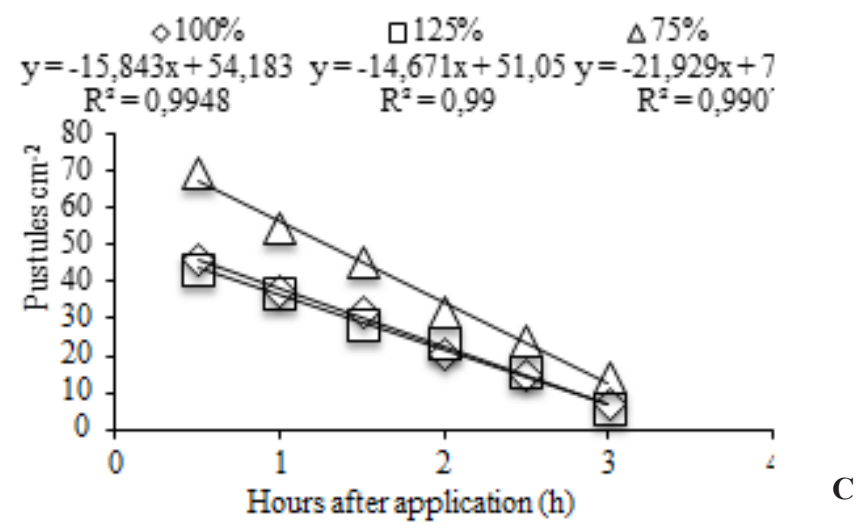

Figure 3 - Simple linear regression for Phakopsora pachyrhizi pustules number in soybean, in function of the rainfall interval time after application for different quantities of fungicide, with the spray volume of 100 (A), 150 (B) e 200 (C) $\mathrm{L} \mathrm{ha}^{-1}$.

\section{ACKNOWLEDGMENTS}

The authors are thankful for the support received from the Postgraduate Program in Agronomy (PPGAgro) of the Universidade de Passo Fundo, in Rio Grande do Sul; and the Coordenação de Aperfeiçoamento de Pessoal de Nível Superior (CAPES).

\section{REFERENCES}

1. Abbott, W.S. A method of computing the effectiveness of on insecticide. Journal of Economic Entomology, Lanham, v.18, n.2, p.265- 267, 1925.

2. Butzen, S.; Marcon, A.; Mcinnes, B.; Schuh, W. Asian soybean rust: fungicide application technology. Crop Insights, Johnston, v.15, n.1, p.1-6, 2005.

3. Cunha, J.P.A.R. da; Moura, E.A.C.; Silva, J.L.J.; Zago, F.A.; Juliatti, F.C. Efeito de pontas de pulverização no controle químico da ferrugem da soja. Engenharia Agrícola, Jaboticabal, v.28, n.2, p.283-291, 2008.

4. Cunha, J.P.A.R. da; Coelho, L.; Araújo, R.G.C. Spray nozzle and adjuvant effects on fungicidal control of soybean Asian rust. Interciência, Caracas, v.35, n.10, p.765-768, 2010.

5. Cunha, J.P.A.R. da; Silva, R.A.M.; Olivet, J.J. Avaliação de pontas e volumes de pulverização na aplicação de fungicida na cultura da soja (Glycine max (L.) Merrill). Revista Facultad Agronomica (Luz), Maracaibo, v. 28, p. 344-359, 2011.

6. Debortoli, M.P. Efeito do "rainfastness" e adjuvante na aplicação de fungicidas foliares em cultivares de soja. 2008. 57 f. Dissertação (Mestrado em Engenharia Agrícola) - Faculdade de Ciências Rurais - Universidade Federal de Santa Maria, Santa Maria.
7. Debortoli, M.P. Efeito dos espectros de gota associados a diferentes arquiteturas de cultivares de soja no controle da ferrugem. 2011. $93 \mathrm{f}$. Thesis (Ph.D. in Agricultural Engineering) - Faculdade de Ciências Rurais - Universidade Federal de Santa Maria, Santa Maria.

8. Debortoli, M.P.; Tormen, N.R.; Balardin, R.S.; Fávera, D.D.; Stefanelo, M.T.; Pinto, F.F.; Uebel, J.D. Efeito dos espectros de gota associados a diferentes arquiteturas de cultivares de soja no controle da ferrugem. Pesquisa agropecuária brasileira, Brasília, v.47, n.7, p.920-927, 2012.

9. Derksen, R.C.; Sanderson, J.P. Volume, speed and distribution technique effects on poinsentia foliar deposits. Transactions of the ASAE, St. Joseph, v.39, n.1, p.5-9, 1996.

10 Embrapa Trigo. Agrometeorologia. Available at: $<$ http://www.cnpt.embrapa. $\mathrm{br} /$ pesquisa/agromet/app/principal/agromet.php $>$. Acessed in: 12 may 2016.

11. Embrapa Trigo. Clima de Passo Fundo. Avalilable at: $<$ http://www.cnpt. embrapa.br/pesquisa/agromet/pdf/Clima_de_Passo_Fundo.pdf $>$. Acessed in: 12 may 2016.

12. Godoy, C.V.; Koga, L.J.; Canteri, M.G. Escala diagramática para avaliação da severidade da ferrugem da soja. Fitopatologia Brasileira, Brasília, v.31, n.1, p.63-68, 2006.

13. Lenz, G.; Balardin, R.S.; Minuzzi, S.P.; Madalosso, M.; Debortoli, M.; Gulart, C.; Ramos, J.P. Espectros de gotas e idade de trifólios e sua interação com a área abaixo da curva de progresso da ferrugem da soja. Ciência Rural, Santa Maria, v.42, p.1528-1534, 2012.

14. Mehl, A.; Scherb, C. T. Detached leaf test method. Available at: <http:// www.frac.info/docs/default-source/monitoring-methods/approvedmethods/phakpa-detached-leaf-monitoring-method-bcs-2006 v1.pdf?sfvrsn=4e9a419a_4>. Acessed in: 12 may 2016.

15. Navarini, L.; Dallagnol, L.J.; Balardin, R.S.; Moreira, M.T.; Meneghetti, R.C.; Madalosso, M.G. Controle químico da ferrugem asiática (Phakopsora pachyrhyzi Sidow) na cultura da soja. Summa Phytopathologica, Botucatu, v.33, n.2, p.182-186, 2007. 
16. Oliveira, A.C.B.; Rosa, A.P.S.A. Indicações técnicas para a cultura da soja no Rio Grande do Sul e Santa Catarina, safras 2014/2015 e 2015/2016. Pelotas: Embrapa Clima Temperado, 2014.

17. Oliveira, S.H.F. Remoção pela chuva de diferentes formulações de flutriafol aplicada em soja, com e sem a adição de óleo mineral na calda. 2009. 94 f. Thesis (Ph.D. in Agronomy) - Faculdade de Ciências Agronômicas - Universidade Estadual Paulista, Botucatu.

18. Pires, N.M.; Ferreira, F.A.; Silva, A.A.; Cardoso, A.A.; Oliveira, V.R. Quantificação dos herbicidas glyphosate e sulfosate na água após simulação de chuva. Planta Daninha, Viçosa, v.18, n.3, p.491499, 2000.

19. Santos, J.A.; Juliatti, F.C.; Santos, V.A.; Polizel, A.C.; Juliatti, F.C.; Hamawaki, O.T. Caracteres epidemiológicos e uso da análise de agrupamento para resistência parcial à ferrugem da soja. Pesquisa Agropecuária Brasileira, Brasília, v.42, n.3, p.443-7, 2007.

20. Sinclair, J.B.; Hartaman, G.L. Soybean rust. In: Hartman, G. L.; Sinclair J. B.; Rupe, J. C. (Eds.). Compendium of soybean diseases. 4 ed. Saint Paul: APS Press, 1999.

21. Tormen, N.R.; Silva, F.D.L.; Debortoli, M.P.; Uebel, J.D.; Dalla Fávera, D.; Balardin, R.S. Deposição de gotas no dossel e controle químico de Phakopsora pachyrhizi na soja. Revista Brasileira de Engenharia Agrícola e Ambiental, Campina Grande, v.16, n.7, p. 802-808, 2012.

22. Yorinori, J.T.; Paiva, W.M.; Frederick, R.D.; Costamilan, L.M.; Bertagnolli, P.F.; Hartman, G.E.; Godoy, C.V.; Nunes Junior, J. Epidemics of soybean rust (Phakopsora pachyrhizi) in Brazil and Paraguay from 2001 to 2003. Plant Disease, St. Paul, v.89, n.6, p.675-677, 2005. 